\title{
外傷性凝固障害とビスコエラスティック デバイス
}

阪本雄一郎*, 小網博之, 三池 徹

\section{Traumatic coagulopathy and viscoelastic device}

Yuichiro SAKAmoto, Hiroyuki KoAmI, Toru Miıke

要約：大量出血に伴う生理学的反応である血液凝固障害は重症外傷で高頻度 に認められるとともに死亡率の独立予測因子であり, 迅速かつ正確に状況を 把握することは治療戦略上極めて重要である。血液凝固障害として一般的に 認められているプロトロンビン時間, 活性化部分トロンボプラスチン時間の 問題点は凝固過程初期の反映である点と血球成分に含まれる血小板の影響が 反映されない点である。分離処理を行わない血液が凝固する過程における 弾性粘稠度変化を測定するビスコエラスティックデバイスとして $\mathrm{TEG}^{\circledR}$, ROTEM $^{\circledR}$ ，Sonoclot ${ }^{\circledR} ，$ T-TAS ${ }^{\circledR}$ などがある。2013 年に American College of Surgeon から報告された ACS TQIP Massive Transfusion in Trauma Guidelinesにお いて外傷性凝固障害や出血性ショックに関する治療戦略に $\mathrm{TEG}^{\circledR} 5000$ と $\mathrm{ROTEM}^{\circledR}$ の検査結果を具体的に示している。 また, ビスコエラスティック デバイスの検査結果と外傷症例の転帰との関連に関しては多くの報告が認め られるが, 外傷症例の輸血管理や転帰改善に有益である明確な根拠はないの が現状である。

Key words: traumatic coagulopathy, viscoelastic device, Thromboelastography $\left(\right.$ TEG $\left.^{\mathbb{B}}\right)$, Rotational Thromboelastometry $\left(\right.$ ROTEM $\left.^{\circledR}\right)$, Total ThrombusFormation Analysis System $\left(\mathrm{T}^{-T_{A} S^{\circledR}}\right.$ )

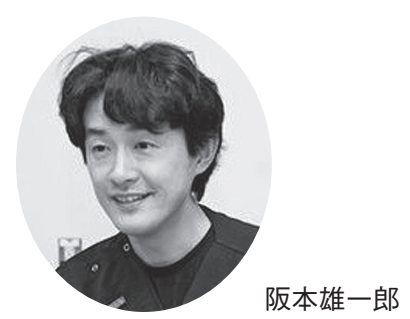

1993年5月 佐賀大学附属病院一 般・消化器外科 研修医

1994年4月 佐賀県立病院好生館 外科 研修医

1995年4月 副島病院外科 医員

1996年4月 佐賀大学一般 - 消化 器外科 医員

1997年4月 唐津赤十字病院外科 医員

1998年4月 佐賀大学一般 - 消化 器外科 医員

1999年4月 佐賀大学一般 - 消化 器外科 研究生

2001年6月 佐賀大学附属病院一 般消化器外科

2002年9月 日本医科大学千葉北 総病院救命救急センター 助 教

2008年4月 日本医科大学千葉北 総病院救命救急センター 病 院講師

2010年3月 佐賀大学医学部非常 災害医療学講座 (寄附講座) 教授

2010年8月 佐賀大学医学部救急 医学講座 教授

\section{1. はじめに}

外傷患者が凝固障害をきたす主な原因は大量出血 による出血性ショックに続発する凝固障害と重症頭 部外傷による凝固障害がある。出血性ショックの治 療は止血が原則となる。出血部の止血が不十分な状 況で輸液や輸血を継続すると止血能の破綻や低体温 による止血能障害をきたす原因となる。よって大量 出血の結果として生じる生理学的変化である血圧低 下ではなく, 大量出血早期の生理学的変化である頻

*責任者連絡先：

佐賀大学救急医学講座

干 849-8501 佐賀県佐賀市鍋島 5-1-1

Tel: 0952-34-3160, Fax: 0952-34-1061

E-mail: sakamoy@cc.saga-u.ac.jp
脈や四肢末梢の湿潤・冷汗, 不安感等で迅速な止血 術までの時間を逸することなく体制を整えることが 重要である。また，外傷性ショックの $90 \%$ 以上であ る出血性ショックの診療においては迅速な止血術と ともに適切な輸血療法を迅速・的確に行うことも極 めて重要である。 大量出血に伴う生理学的反応であ る血液凝固障害は重症外傷において高頻度に認めら れるとともに死亡率の独立予測因子であり, 迅速か つ正確に状況を把握することは治療戦略上極めて重 要である.

外傷診療の治療戦略は, 根治的な止血術や損傷修 復によって一旦，凝固障害をきたしてしまうと致命 的となるため，可及的止血術を短時間で行い術後の 集中治療によって生理学的徴候を回復させた後に必 要に応じた計画的再手術で損傷修復を完結させる 
damage control surgery (DCS)の概念が重要であると 認識されている.

ここで重要となってくるのは, 外傷性凝固障害の 程度や状況を迅速かつ客観的指標で把握することで ある。例えば凝固能が破綻した状況において止血目 的の外科的手術を継続しても制御不能な出血により 止血術を完結することもできず，結果的に救命し得 ないという結果を招きかねない。このような状況を 避けるために DCS 決断のための基準として外傷死 の 3 徵いわゆる deadly triad と呼ばれる低体温, 代 謝性アシドーシス, 血液凝固障害が知られている ${ }^{1)}$. 実際の臨床現場においても体温と酸塩基平衡は迅速 に測定できるが血液凝固障害の検査結果として一般 的に挙げられるプロトロンビン時間 (prothrombin time: PT), 活性化部分トロンボプラスチン時間 (activated partial thromboplastin time: APTT)の検查結果 は結果判明までに少なくとも 30 分以上を要し，検 査結果自体も凝固過程初期の反映でありこの時期の トロンビン産生量は全体の約 $5 \%$ に過ぎないといわ れている。また，血漿成分を分離させた後に凝固促 進剤を加えて測定された結果であるため血球成分に 含まれる血小板の影響が反映されない検査結果とな り, 必ずしも生体内の凝固能を正確に反映し得ない 場合もあると考えられる。また，全血を用いる検査 である活性化凝固時間 (activated whole blood clotting time: ACT) も PT, APTT と同様にフィブリンゲル形 成時点で測定を中止するためトロンビン産生量の約 $5 \%$ の時点となり生体における血液凝固能を正確に 反映できない場合もあると考えられる21.

\section{2. ビスコエラスティックデバイスの測定原理}

分離処理を行わない血液が凝固する過程における 弾性粘稠度変化を測定する機器として Thromboelas$\operatorname{tograph}\left(\mathrm{TEG}^{\circledR}\right)$ が 1948 年に初めて報告されている ${ }^{3)}$. 現在, 一般的な凝固能検査として浸透している PT や APTTが血漿成分のみの検査であり問題点は前述 しているが，PT， APTTより TEGの方が先に報告さ れていた。しかし, TEG 報告時には血液凝固カスケー ドも未解明の時期であり粘稠度測定が病態の解明に 有益であるとの証明にはいたらず一般的な検査とし て定着しなかった。その後，1985 年に肝臓移植手術
中の凝固能モニタリングに関する有効性の報告がな され，臨床応用が広がっている ${ }^{4)}$. 現在，普及して いるビスコエラスティックデバイスは TEG の他に Thromboelastometry $\left(\right.$ ROTEM $\left.^{\circledR}\right)$ および Sonoclot ${ }^{\circledR}$ が一 般的である。また，従来の凝固止血機能を評価する POC (point of care) 機器と, 測定原理が全く異なった 機器が本邦において開発されている。この機器は Total Thrombus-Formation Analysis System $\left(\right.$ T-TAS $\left.^{\circledR}\right)$ で あり，測定原理に関しては後述する。

一般的な POC 機器の測定原理は, $\mathrm{TEG}^{\circledR} 5000$ およ び ROTEM ${ }^{\circledR}$ delta の測定原理，つまりキュベット内 に全血の血液サンプルと凝固活性剤を入れて血液 サンプルに浸したピンによって形成される血栓形成 の粘稠度をピンに加わる機械的インピーダンスを光 学センサーにより測定する。 ROTEM ${ }^{\circledR}$ が全血サン プルに浸されたピンが $\pm 4.75^{\circ}$ 回転するのに対して $\mathrm{TEG}^{\circledR}$ は全血サンプルを入れたキュベットを収めた ホルダーが $0.1 \mathrm{~Hz}, \pm 4.75^{\circ}$ で左右に往復回転する点 が異なる。一方，現時点における $\mathrm{TEG}^{\circledR}$ の最新機種 である $\mathrm{TEG}^{\circledR} 6 \mathrm{~s}$ は，測定原理が機械的インピーダン スではなく超音波による音響インピーダンスであ る. $\mathrm{ROTEM}^{\circledR}$ と $\mathrm{TEG}^{\circledR} 5000$ の測定原理はピンが回 転するかキュベットが回転するかの違いであるが全 血サンプルに加える試薬が異なるため二つの機器に よる検査結果を単純比較することはできない，ま た， ROTEM ${ }^{\circledR}$ delta の方が加える試薬が多いため $\mathrm{TEG}^{\circledR} 5000$ よりも測定項目が増える.

ROTEM $^{\circledR}$ の測定は， 2 種類の液状試薬をクエン酸 加の全血サンプルが入ったキュベットに加えて行 う。この 2 種類の試薬の組み合わせによって 5 種類 の測定項目を選択する。試薬は 6 種類ありそれぞれ 以下のような試薬である。塩化カルシウムを含みク エン酸を含む採血スピッツ内の血液の凝固を促進す る star-tem, エラジン酸を含み接触相を活性化する in-tem, ヘパリナーゼを含みヘパリンを分解する hep-tem，組織因子を含み外因系凝固を活性化する rex-tem, サイトカラシン D を含み抗血小板作用を有 する fib-tem, アプロチニンを含み抗線溶作用を有す る ap-tem, 以上 6 種類の液状試薬を組み合わせて一 般的には 5 種類の検査が可能となる。測定項目に用 いる試薬と検査結果の特徵としては以下のごとくで ある。液状試薬 star-tem と in-tem(シングルユース 


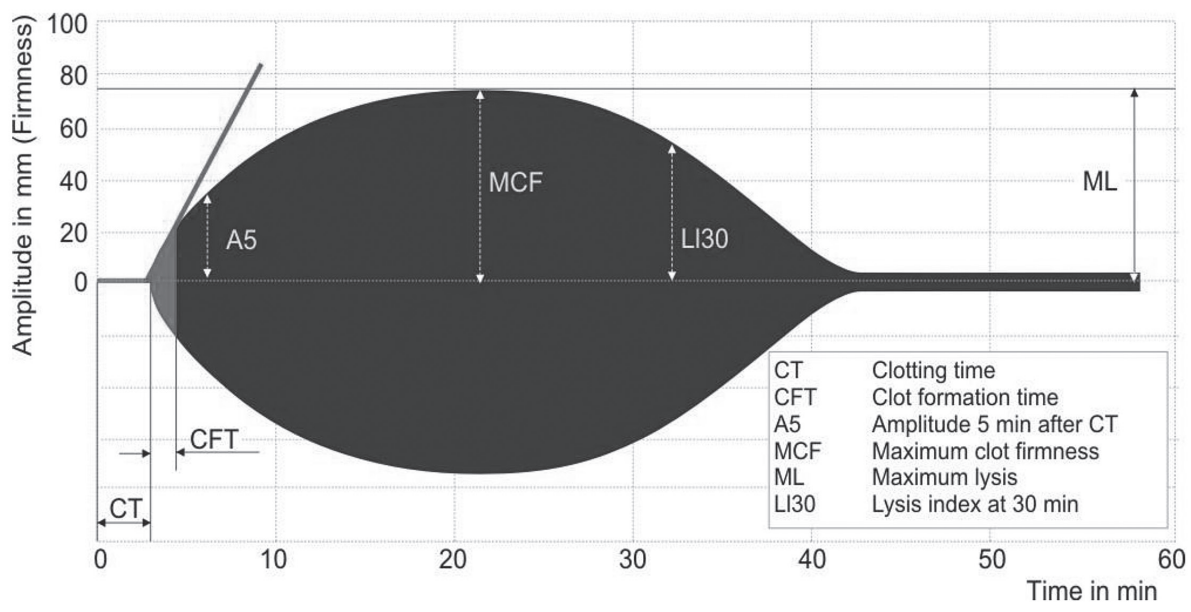

図 1 ROTEM の測定結果

ROTEM の HP より (https://www.rotem.de/en/)

試薬では in-temS）を加えたINTEM は内因系凝固の 活性化を表し, 検体中のへパリンの影響を強く受け る。液状試薬 in-tem と hep-tem(シングルユース試 薬では hep-tem S) を加えた HEPTEM はへパリンを ブロックした状態での内因系凝固の活性化を表して おり，プロタミンとへパリンのバランスを評価でき るのが特徵である。液状試薬 star-tem と rex-tem(シン グルユース試薬では ex-temS) を加えた EXTEM は外 因系凝固の活性化を表しており，10 分ほどで測定で きる。液状試薬 rex-tem と fib-tem(シングルユース 試薬では fib-temS) を加えた FIBTEM は血餅重合に おける血小板の影響を除いたフィブリノゲンのみの 影響を評価できる。液状試薬 rex-tem と ap-tem(シン グルユース試薬では ap-temS) を加えた APTEM は線 溶㐫進を迅速に評価可能であり，抗線溶薬の効果も モニタリング可能である。また，試薬の組み合わせ によって最大 8 種類の検査が可能である.

$\mathrm{ROTEM}^{\circledR}$ では, こうした検査項目を同時に 4 つ測 定することが可能であり，用途に応じて測定する項 目やそのタイミングを調整することができるのも大 きな利点である。

$\mathrm{ROTEM}^{\circledR}$ での測定結果は, 横軸を時間(分), 縦 軸は上下方向に，血栓硬度に相当する振幅 $(\mathrm{mm})$ で 表す（図 1)。測定開始から凝固が始まるまでの凝固 時間 (clotting time: CT) や, 凝固開始から血栓硬度が $20 \mathrm{~mm}$ に達するまでの時間 (clot formation time: CFT) とその角度 (alpha angle: $\alpha$ ), 凝固開始から 5 分毎の
血栓硬度 (amplitude: A 5-30) とその最大值 (maximum clot firmness: MCF)，凝固開始から 30，45，60 後の 線溶指標 (lysis index: LI 30，45，60) と最大線溶指標 (maximum lysis: ML) などの様々なパラメータが，リ アルタイムにモニターに把握できる，健常人では図 2 のごとく表示されるのに対し, 血小板機能不全では, EXTEMの血栓硬度が低下している割には，FIBTEM では健常人と類似した波形が見られる(図 $3 \mathbf{A}$ )。一 方，EXTEMの血栓硬度が低下し，FIBTEMの血栓 硬度も低下していれば，フィブリノゲン機能不全が 考えられる(図 3B)。ささらに血栓硬度が最大となった あとに，血栓硬度が小さくなれば線溶による影響や 血餅退縮などを考えるが，EXTEM や FIBTEMの血 栓硬度が MCF に比べて $15 \%$ 以上小さくなるのに対 し, APTEM で線溶が抑制されていれば，線溶立進と 診断できる(図 3C)。この他にも，INTEM の凝固時 間が延長している場合に HEPTEM の凝固時間が，短 縮していれば, ヘパリンの影響を考慮する（図 3D）。

一方の $\mathrm{TEG}^{\circledR} 5000$ の測定は，あらかじめ製品化さ れている試薬をクエン酸加もしくはヘパリン加の全 血サンプルが入ったキュベットに加えて行う。 $\mathrm{TEG}^{\circledR} 5000$ の試薬は, 基本検査の試薬でもある内因 系凝固を活性化するカオリン，ヘパリンの影響を排 除するへパリナーゼ，外因系凝固を活性化する組織 因子，不完全なフィブリン産生を生じるバトロキソ ビン，強制的にフィブリン網を形成させる活性化第 13 因子，それぞれ特定の血小板レセプターを活性 

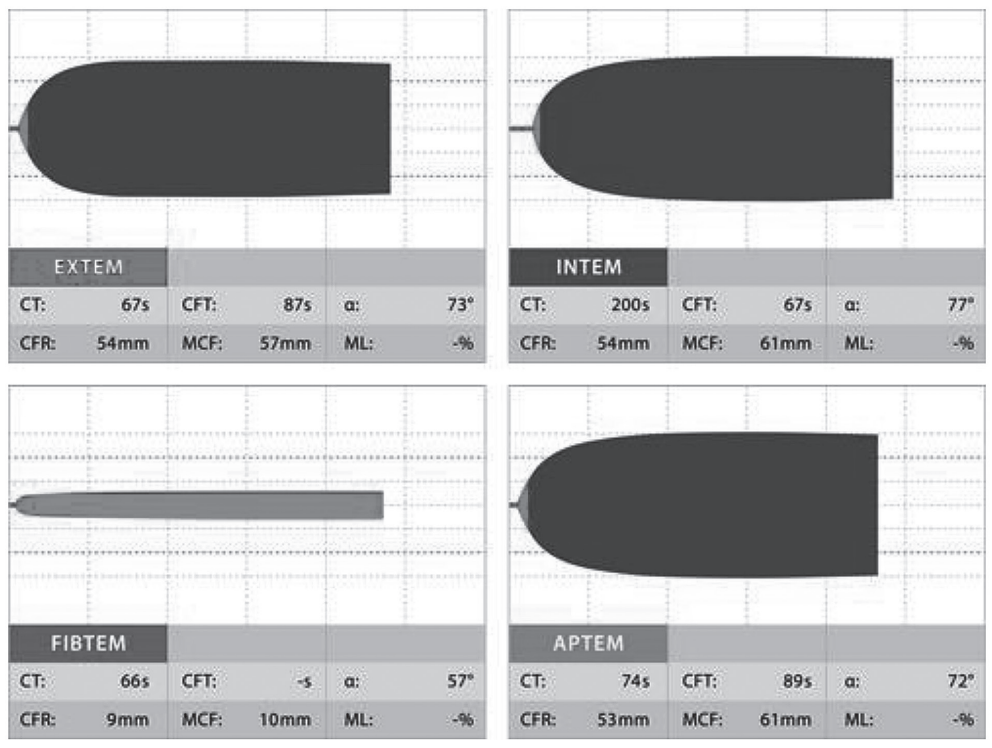

図 2 健常人の ROTEM 結果

ROTEM の HP より (https://www.rotem.de/en/)

\section{A. 血小板機能不全}

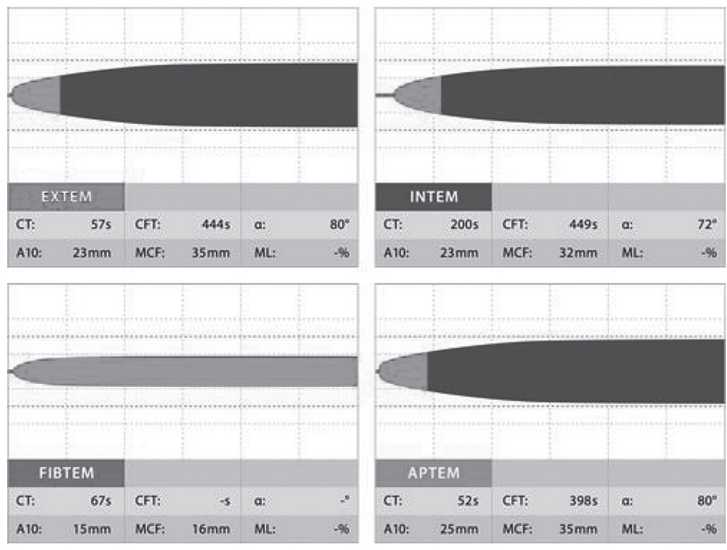

B. フィブリノゲン機能不全
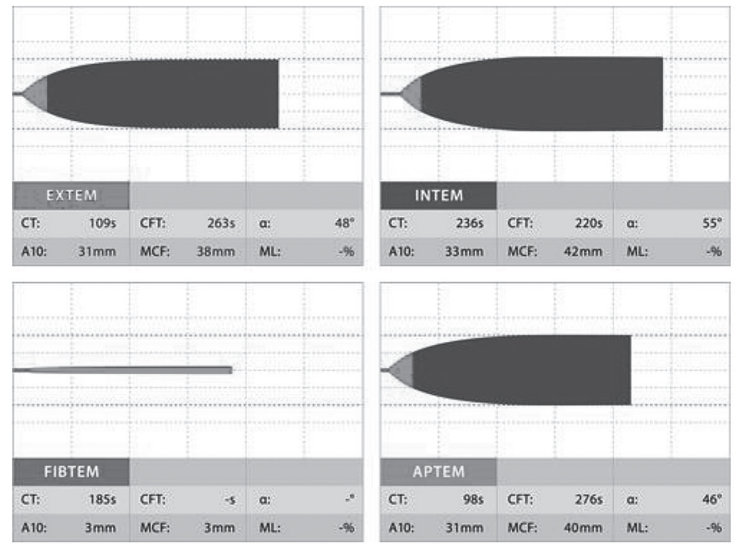

C. 線溶六進
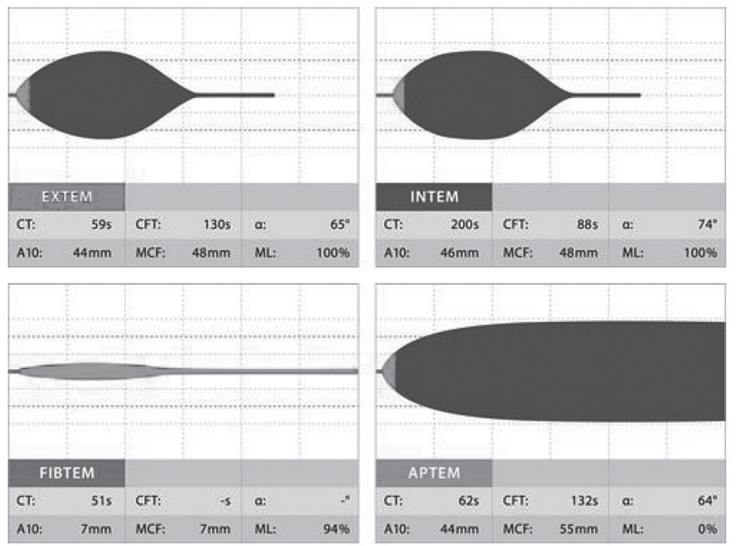

D. ヘパリンの影響

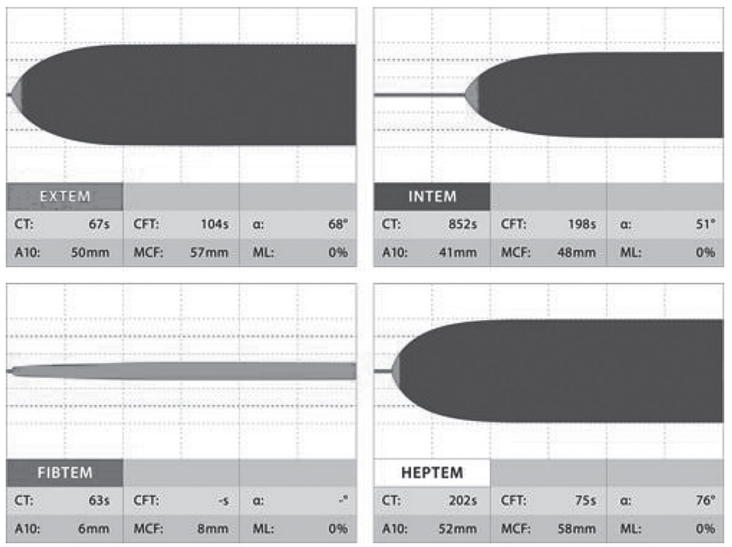

図 3 各病態ごとの ROTEM 結果

ROTEM の HP より (https://www.rotem.de/en/) 


\section{Measure all phases of hemostasis in whole blood.}

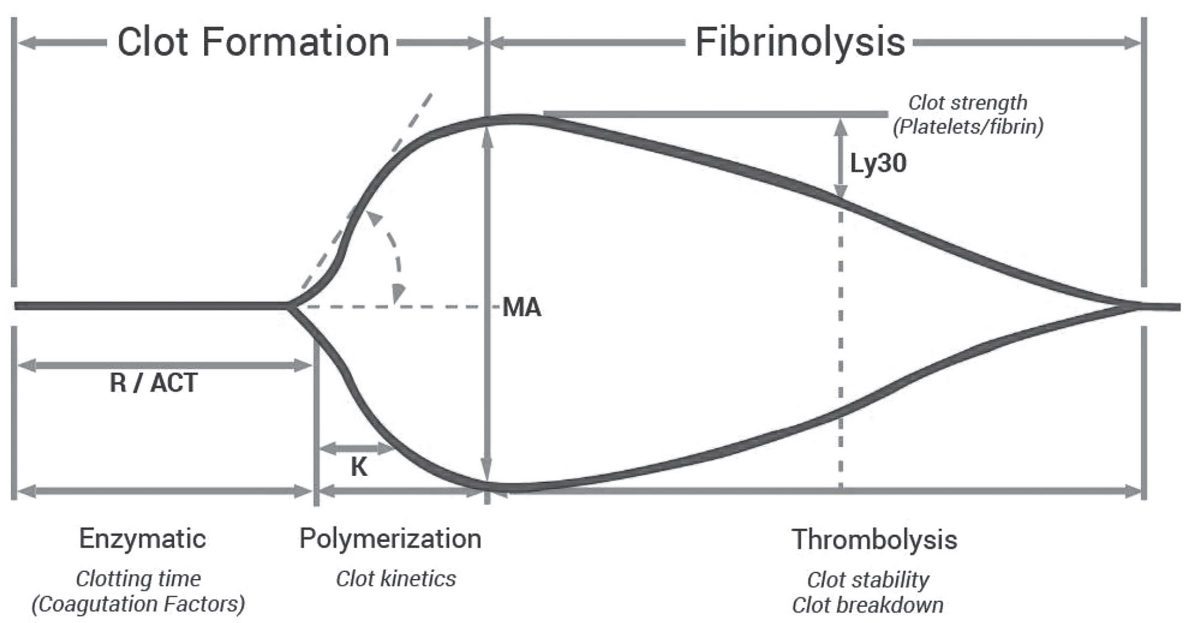

The TEG ${ }^{\circledR}$ hemostasis system continuously measures all phases of hemostasis as a net product of whole blood components

図 4 TEG の測定結果

Haemonetics 社の HP より (http://teg.haemonetics.com/en-GB)

化するアラキドン酸 (arachidonic acid: AA)，アデノ シン二燐酸 (adenosine diphosphate: ADP), 血小板凝 集抑制のアブキシマブ，以上 7 種類を組み合わせた 6 種類の試薬によって 6 種類の検査が可能となる. 測定項目に用いる試薬と検査結果の特徵としては以 下のごとくである。 カオリンを加えた Kaolin TEG は $\mathrm{TEG}^{\circledR}$ の基本的な検査であり内因系の凝固活性を表 している。 カオリンとへパリナーゼを加えた Kaolin TEG+Heparinase はへパリンの影響を検出できる。 カ オリンと組織因子を加えた Rapid $\mathrm{TEG}^{\circledR}$ は血餅形成 能の迅速診断が可能である。組織因子とアブキシマ ブを加えた TEG functional fibrinogen はフィブリン 重合能の評価が可能である。 また， $\mathrm{TEG}^{\circledR} の$ 特徵で もある血小板機能を測定する検査項目は，バトロキ ソビンと活性化第 13 因子, アラキドン酸を加えた検 査とバトロキソビンと活性化第 13 因子, アデノシン 二燐酸を加えた検査がある。いずれも $\mathrm{TEG}^{\circledR}$ platelet mapping と呼ばれておりそれぞれアスピリンの影響 の検出と P2Y12 阻害薬の影響検出が可能である.

$\mathrm{TEG}^{\circledR}$ の測定結果は図 4 に示す。 ROTEM ${ }^{\circledR}$ と同じ ように，横軸に時間，縦軸に血栓硬度をとるグラフ で表され，凝固開始までの時間 (R time)や R time か ら血栓硬度が $20 \mathrm{~mm}$ に達するまでの時間 (K time),
血栓硬度 (MA)，そして線溶指標(LY30)である。

$\mathrm{TEG}^{\circledR}$ と ROTEM ${ }^{\circledR}$ は基本的な測定原理は同じであ り，得られる検査結果をまとめると表 1 のようにな る。 $\mathrm{TEG}^{\circledR}$ は，内因系凝固経路ならびにへパリンの 影響を評価するのは可能だが，外因系凝固経路や線 溶克進の有無は評価できない。さらに，各時間での 血栓硬度の評価はできない。しかし，内因系と外因 系の両方を賦活化して短時間で凝固異常を同定でき る Rapid $\mathrm{TEG}^{\circledR}$ は，迅速性に長けており救急外来や 手術室などで多く使用されている。また，同じ器械 を用いて血小板機能まで評価できるのも有用である.

一方 ROTEM ${ }^{\circledR}$ は，内因系や外因系の凝固経路に対 して多彩なパラメータをリアルタイムに把握し, 解 析することが可能である。ささらに，線溶立進の診断

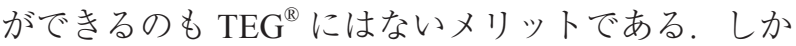
し，血小板機能の測定には，ROTEM ${ }^{\circledR}$ platelet という 別の装置が必要である。近年, $\mathrm{TEG}^{\circledR}, \mathrm{ROTEM}^{\circledR}$ と もに測定時間の短縮化のために, $\mathrm{TEG}^{\circledR} 6 \mathrm{~s}, \mathrm{ROTEM}^{\circledR}$ sigma が開発された。 $\mathrm{TEG}^{\circledR} 6 \mathrm{~s}$ は, 専用のカートリッ ジを挿入し，クエン酸加血液を一度注入するだけ で，4項目の測定が自動的に行われる。 ROTEM ${ }^{\circledR}$ sigmaは，こちらも専用のカートリッジを挿入し，採 血をしたスピッッ毎そのカートリッジに差し込むこ 
表 1 おもな ROTEM と TEG の検査項目

\begin{tabular}{|c|c|c|}
\hline $\mathrm{TEG}^{\circledR}$ & ROTEM $^{\circledR}$ & 反映する全血の性状 \\
\hline $\mathrm{R}$ (reaction time) & $\mathrm{CT}$ (clotting time) & フィブリン形成までの時間. \\
\hline $\mathrm{K}$ (clot kinetics) & CFT (clot formation time) & $\begin{array}{l}\mathrm{R}, \mathrm{CT} \text { から振幅が } 20 \mathrm{~mm} \text { になるまでの時間. } \\
\text { フィブリン網形成の時間を反映. }\end{array}$ \\
\hline$\alpha$ & $\alpha$ & 振幅の増加率. フィブリン産生速度を反映. \\
\hline A (amplitude) & A (amplitude) & $\begin{array}{l}\text { 凝血塊の弾性粘稠度. 血小板数と機能および } \\
\text { フィブリン産生能と濃度を反映. }\end{array}$ \\
\hline MA (maximum amplitude) & $\mathrm{MCF}$ (maximum clot firmness) & 振幅の最大值. 血塊の強さを反映. \\
\hline \multirow[t]{2}{*}{ LY30, LY60 } & LI30, LI45, LI60 & $\begin{array}{l}\text { 最大振幅後の } 30 \sim 60 \text { 分後の減少率. 線溶元 } \\
\text { 進を反映. }\end{array}$ \\
\hline & ML (maximum lysis) & $\begin{array}{l}\text { MCF 到達後の振幅最大減少率. 線溶圥進の } \\
\text { 程度を反映. }\end{array}$ \\
\hline
\end{tabular}

とで，血液を扱うことなく測定が可能である.

一方 Sonoclot ${ }^{\circledR}$ は, 1975 年に報告された凝固モ二 タリング装置であり ${ }^{5)}$, ROTEM $^{\circledR}$ や $\mathrm{TEG}^{\circledR} 5000$ と同 様に血栓形成過程における血液粘稠度の变化を測定 する点は同様である，相違点としては全血の血液 サンプルを入れるキュベットの内側にあらかじめ凝 固活性剂を添付している点と，検体内に沈めた筒状 プローベを $200 \mathrm{~Hz}$ で上下振動させ検体の凝固反応 によって生じる粘稠度変化によって生じるプローベ 卜検体間のずり応力変化をトランスデューサーが検 知する機器である. Sonoclot ${ }^{\circledR}$ は機器によっても測定 できる範囲が異なっており，モデル $\mathrm{SC} 1$ という機種 は activated clotting time (ACT) に加えフィブリンゲ ルの形成度を評価する clot rate $(\mathrm{CR})$ の測定のみ可能 である。また，モデル SCP1，SCP2 という2 機種は $\mathrm{SC} 1$ の測定に加え platelet function $(\mathrm{PF})$ と線溶系の測 定まで可能となっている.

Sonoclot $^{\circledR}$ の測定は，あらかじめ試薬が添加されて いる測定用キュベットにクエン酸添加もへパリン添 加も行われていない採血したシリンジ内の全血サン プルを加えて行う。キュベットの種類は 6 種類であ り添加されている試薬は基本検査の試薬でもある内 因系凝固を活性化するカオリン，セライト凝固を非 選択的に活性化するガラス粒。ヘパリンの影響を排 除するへパリナーゼ．以上 4 種類の試薬の組み合わ せとプローブの形状によって 5 種類の検査を可能に している。 キュペットに添加されている薬荗と検査 の特性としてはカオリンが添付されている $\mathrm{kACT}$
KIT は高用量の抗凝固のモニタリングに適してお り，血小板機能はモニタリングしない。また，カオ リンはメシル酸ナファモスタットを吸着するのでメ シル酸ナファモスタットのモニタリングの際にはガ ラス粒の添加キュペットを用いる。 セライトが添加 されている SonACT KIT は高用量の抗凝固, 線溶卉 進のモニタリングに適しており，低分子へパリンは CR でモニタリングが可能である。 ガラス粒が添加 されている $\mathrm{gbACT}+\mathrm{KIT}$ は低〜中用量の抗凝固モ二 タリングに加え抗トロンビン製椷，Xa 阻害薬のモニ タリング，抗血小板凝集薬等凝固能と血小板機能全 般におけるモニタリングが可能である。ガラス粒が 添加されたキュペットに穴開きプローブを組み合わ せた gbACT+KIT with fenestrated probes は肝臓移植 手術の凝固能検查に適している。また, ヘパリナー ゼとガラス粒が添加された H-gbACT+KIT は人工心 肺や PCPS, ECMO などへパリンを使用している状 態におけるへパリンの影響を除いた凝固能や血小板 機能の検査が可能である.

実際の測定結果は $\mathrm{ACT}, \mathrm{CF}, \mathrm{PF}$ の数值表示に加え, 専用ソフト Signature Viewer を用いた場合には PC 機 器の結果の波形表示も得られる。典型的な結果表示 は図 5 のように表示される。ACT は液状で抵抗も 少なかった血液がフィブリンゲル形成の始まりから 固まり始めるまでの時間で, フィブリンゲル形成の 度合いを数值化したものが CR である。CR の測定 は凝固六進のモニタリング，抗凝固薬管理，血液希 釈による凝固能低下等に有用となる。その後全血が 


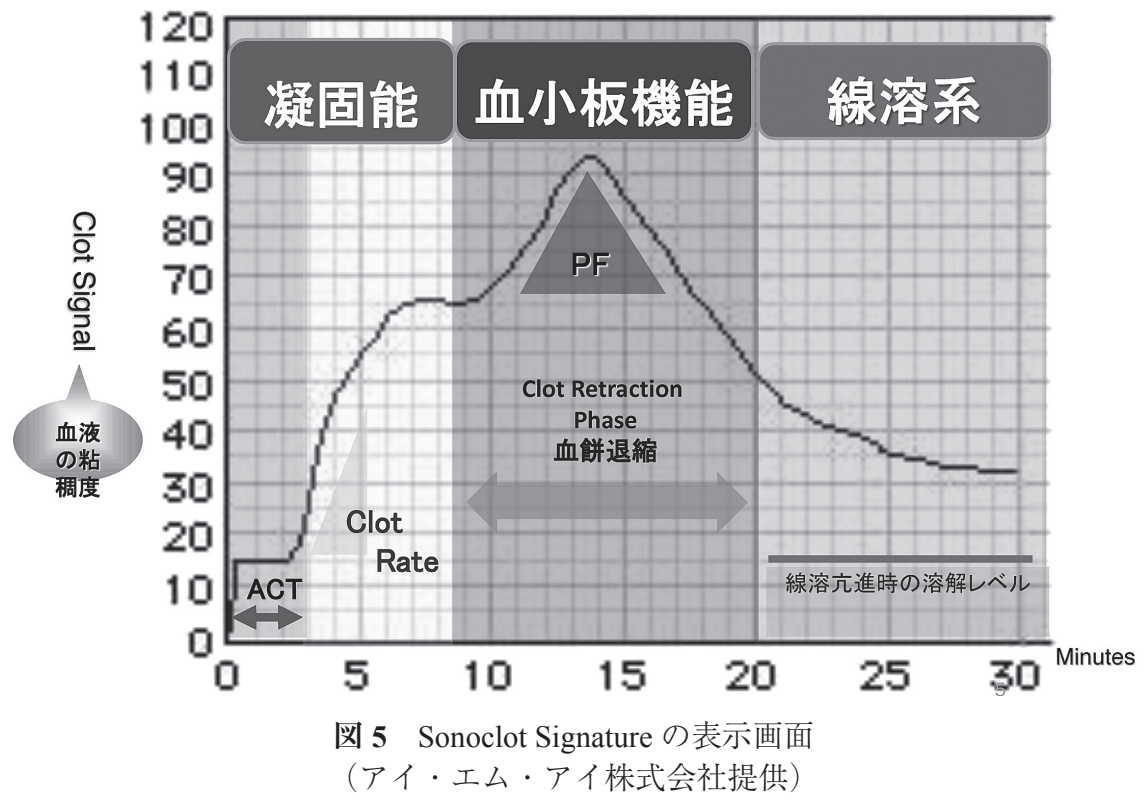

\section{$100 \%$ 新鮮棟結血頻}

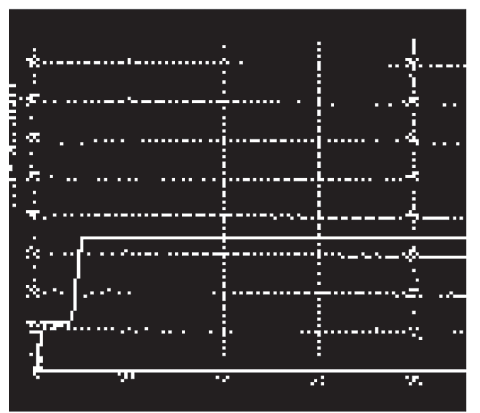

\section{新鮮棟結血频 +}

\section{5\%禯厚血小板血龊}

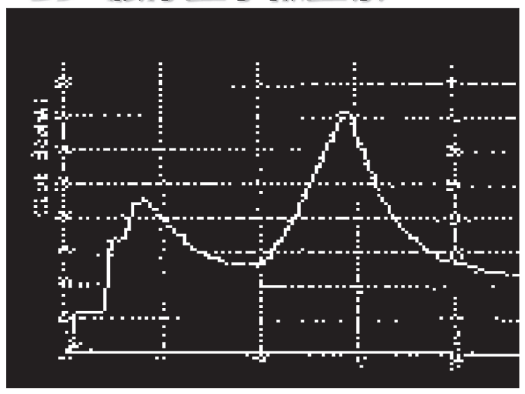

\section{新鮮棟結血频 +}

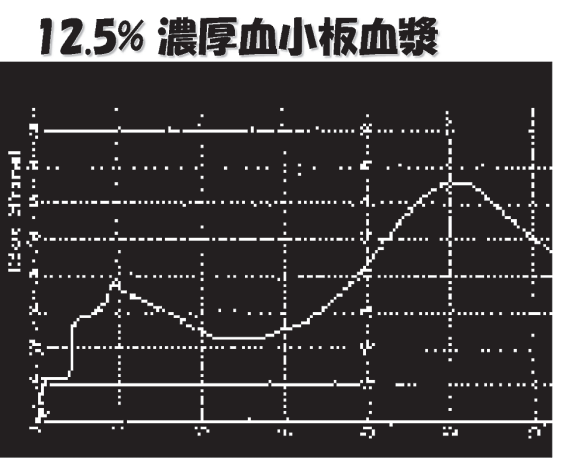

\section{新鮮凍結血数 +}

\section{0\%濃厚血小板血䇰}

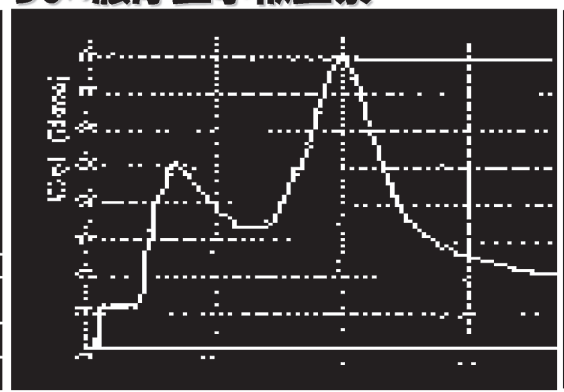

\section{0\%濃厚血小板血龊}

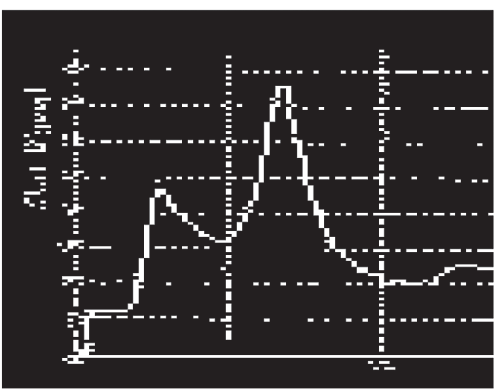

図 6 新鮮凍結血漿 + 濃厚血小板血漿の表示画面 （アイ・エム・アイ株式会社提供）

凝固した際にフィブリン血栓が血小板の収縮性蛋白 の作用により退縮し血清を析出する。この反応を血 餅退縮といい血小板糖蛋白 GPIIb/IIIa の関与が大き
く血小板機能を反映する，実際の血餅退縮の変化は 図 6 のように新鮮凍結血漿 100\%から濃厚血小板血 漿の濃度が増すほどピークの上昇として表示される。 
線溶え進時の波形

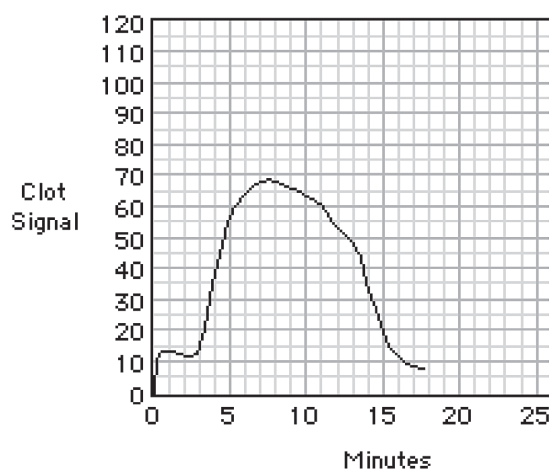

抗線溶薬(トラネキサム酸) 投与後の波形

Clot

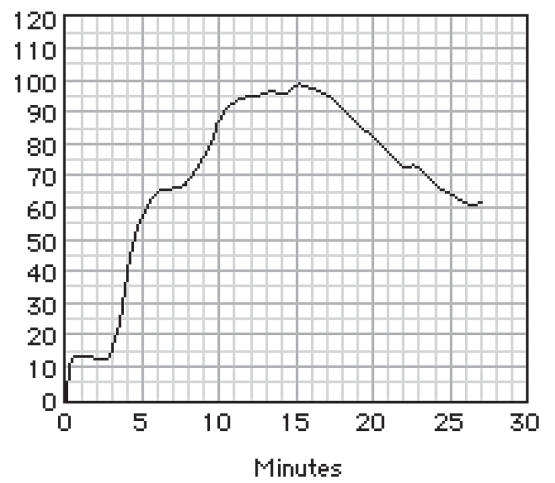

A $\mid$ B

図 7 線溶立進時と抗線溶薬によって改善した際の波形 （アイ・エム・アイ株式会社提供）

血餅退縮が強く血小板機能が強いとピークが鋭く表 示され，血餅退縮が弱く血小板機能が弱いとピーク の勾配が緩く表示される。線溶光進 (hyperfibrinolysis）は, ピーク後の clot signal として表示され線溶 立進時には図 7A のように元の液状のレベルより下 がり, 図 7B の波形は抗線溶薬(トラネキサム酸) 投 与によって clot signal の上昇が確認された例である。

T-TAS ${ }^{\circledR}$ の測定原理は，模擬血管であるチップに一 定流量のサンプルである全血を流し，模擬血管内に 形成される血栓を経時的に観測する機器である。血 栓形成速度や血栓硬度は圧曲線に反映されるため, その曲線から全血の凝固活性や血小板機能を評価す ることができる。模擬血管を内蔵したチップは二種 類あり，それぞれPLチップ(PL-chip)・ARチップ (AR-chip) と呼ばれている.

PL チップは血小板機能評価に特化したチップであ り，コラーゲンで覆われた模擬血管を有するチップ である．抗トロンビン薬であるヒルジンで抗凝固処 理をした検体を使用し，血栓形成能の評価を行う。 血小板はVWF(von Willebrand factor)を介して模擬血 管内のコラーゲンと結合し，ずり応力が発生する. ずり応力により血小板は活性化し，フィブリノゲン やVWFを介達した凝集が引き起こされ血栓を形成 していく原理である。P チップを使用した実際の 測定画面を図 8 に示す。小型カメラで撮影された模 擬血管内の様子を, 右上ウインドウでリアルタイム に観察することが可能である。また右下ウィンドウ
で示されるグラフは，横軸を時間・縦軸を計測圧で 示したものである。経時的に表示される圧曲線によ り，われわれは血栓形成能をヴィジュアル的に捉え ることができる。本装置では模擬血管に流す血流量 や血管温度など血流条件を測定者が自由に設定する ことが可能となっている。つまりこの装置は身体の 様々な血管での血栓形成状態を，任意にシミュレー ションすることができる装置と言える。もう一つの AR チップは，コラーゲンと組織因子で覆われた模 擬血管を有するチップである。 クエン酸ナトリウム にて抗凝固処理を行った全血は，カルシウムイオン 添加後に模擬血管内でコラーゲンと組織因子により 活性化される。活性化した血小板と凝固因子によ り，模擬血管内には非常に強固な血栓が形成され る。この AR チップを使用することで，血小板機能 と凝固能を併せた血栓形成能を測定することが可能 であるＡRチップによる測定画面を図９に示すが， 測定画面の構成はPLチップ使用時と同様である. $\mathrm{T}^{-} \mathrm{TAS}^{\circledR}$ に内蔵された血栓解析ソフト $\mathrm{T}-\mathrm{TAS}^{\circledR} \mathrm{Zia}$ (図 10）を使うことで，この AR チップの模擬血管に形 成される血栓の詳細な観察も可能となっている(最 新機種の T-TAS plus ${ }^{\circledR}$ では, PLチップに形成される 血栓解析も可能となっている).

他の一般的な POC 機器と T-TAS の最大の違いは, 理論上最も生理的な血栓形成能評価が可能であると いう点であろう。他の POC 機器による測定方法や 検査室で行われている PT (prothrombin time)や APTT 

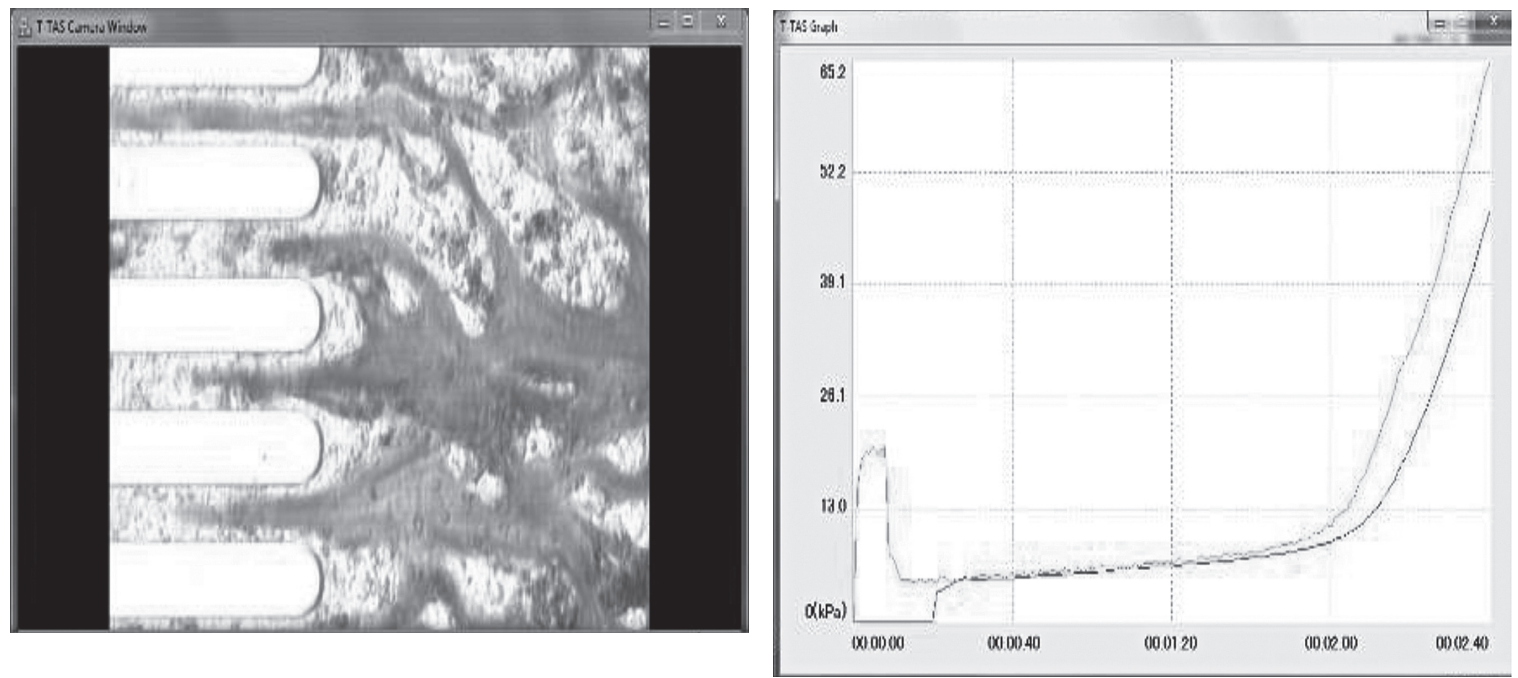

図 8 PL チップを使用した実際の測定画面 (藤森工業株式会社提供)
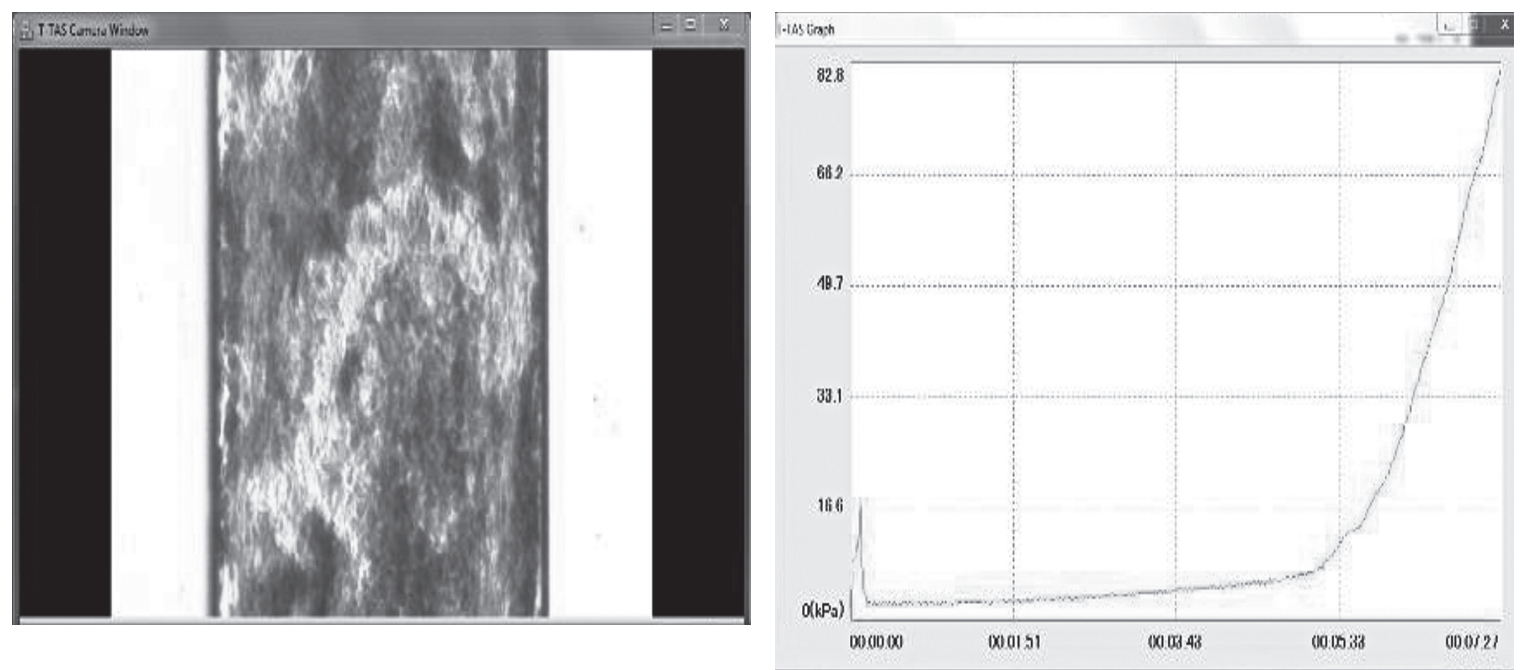

図 $9 \mathrm{AP}$ チップを使用した実際の測定画面

(藤森工業株式会社提供)

(activated partial thromboplastin time) などの凝固検査 は, 凝固誘発のための試薬を検体に直接添加し混和 させている，一方，T-TAS は模擬血管のコラーゲン や組織因子が検体の一部を活性化し，それが引き金 となり生体内で起きるような生理的な血栓形成を引 き起こす機器である。また他の POC 機器と異なり模 擬血管を利用しているため, 血行力学的な観点から も生理的であると考えられる。そのためこの $\mathrm{T}-\mathrm{TAS}^{\circledR}$ を使用した血栓形成能の評価は, 他の凝固モニ夕 リングのための POC 機器と異なり，わずかな血小
板機能・凝固機能の変化を鋭敏に捉えることが可能 である。

外傷性凝固障害に関連した欧米のガイドラインにお けるビスコエラスティックデバイスの位置づけ

外傷性凝固障害に関する欧州における外傷症例の 治療戦略における重要度は, 外傷性出血に対するガ イドラインを報告した論文のタイトルからも読み取 ることができる。 2007 年に報告された論文のタイト ルが Management of bleeding following major trauma: a European guideline $^{6}$ であるのに対して 2013 年に新た 


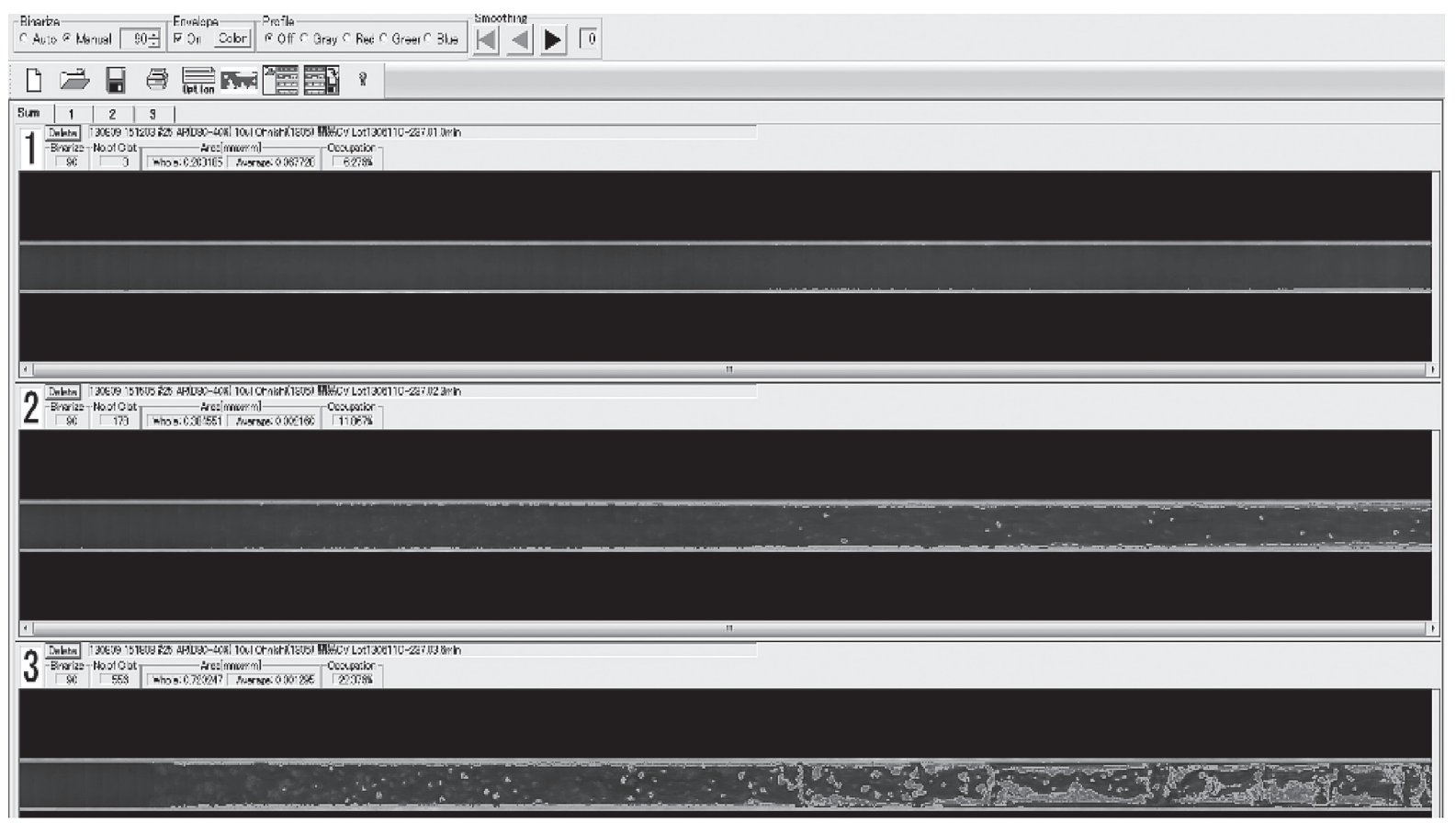

図 10 模擬血管に形成される血栓の詳細な観察画面 (藤森工業株式会社提供)

に報告された論文のタイトルには Management of bleeding and coagulopathy following major trauma: an updated European guideline ${ }^{7)}$ と論文タイトルに coagulopathy の文字が加わっており, 凝固障害に対する治 療戦略上の重要度が高くなっていると考えられる。 この 2013 年の新しいガイドラインにおいて出血性 ショック症例の治療戦略を決定するうえでのビスコ エラスティックデバイスに関する記述としては凝固 障害の状況判断や治療戦略に有益であると記されて いる(Grade 1C)，この欧州のガイドラインをみても 外傷性凝固障害の病態把握に対するビスコエラス ティックデバイスの重要性は欧州において広く認識 されていると考えられる。

一方, 米国においては 2013 年に American College of Surgeon から報告された ACS TQIP Massive Transfusion in Trauma Guidelines において外傷性凝固障害 や出血性ショックに関する治療戦略として血漿, ク リオ製剤，血小板，抗線溶製剤の投与基準にビスコ エラスティックデバイスである $\mathrm{TEG}^{\circledR} 5000$ と ROTEM ${ }^{\circledR}$ の検査結果を具体的に示している ${ }^{8)}$ 。この記載から みても外傷診療が進んでいる米国において外傷性凝 固障害におけるビスコエラスティックデバイスの臨
床利用は，わが国よりも進んでいると考えられる． このガイドラインによると $\mathrm{TEG}^{\circledR}$ が使用可能な状況 であれば以下のような基準が記されている，血漿補 充の指標は reaction (R)-time $>9$ 秒，血漿製凨および/ またはクリオ製剤(またはフィブリノゲン製剤)の補 充の指標は K-time $>9$ 秒。クリオ製剂 (またはフィブ リノゲン製剤)および/または血漿製剤の補充の指標 は a angle $<60^{\circ}$ ．血小板製荗補充の指標は maximum amplitude (MA) $<55 \mathrm{~mm}$. トラネキサム酸等の抗線溶 製剂補充の指標は $\mathrm{LY} 30>7.5 \%$ 。また $\mathrm{TEG}^{\circledR}$ の中でも rapid $\mathrm{TEG}^{\circledR}$ が測定可能な場合の指標としては以下の ように記述されている。血漿製剤の補充は ACT $>128$ 秒。血漿製剤掞よび/またはクリオ製剤(またはフィ ブリノゲン製剂)の補充の指標は K-time $>2.5$ 秒。ク リオ製剤(またはフィブリノゲン製剤)およびはたは 血漿製剂の補充の指標は $\alpha$ angle $<60^{\circ}$ ，血小板製剂 補充の指標は $\mathrm{MA}<55 \mathrm{~mm}$. トラネキサム酸等の抗 線溶製剂補充の指標は LY30>3\%。一方, ROTEM ${ }^{\circledR}$ が測定可能な場合の指標は以下のような記載となっ ている。血小板製剤補充の指標は EXTEMの CT が $>100$ 秒および/または INTEMのCT が>230秒。ク リオ製剤(またはフィブリノゲン製椷)およびはたは 
血漿製剤の補充の指標は FIBTEM の MCF が $<8 \mathrm{~mm}$. 血小板製剂補充の指標は EXTEM の $\mathrm{MCF}<45 \mathrm{~mm}$ お よび FIBTEM の MCF $>10 \mathrm{~mm}$. トラネキサム酸等の 抗線溶製剂補充の指標は EXTEM の ML が>15\%。

\section{ビスコエラスティックデバイスの外傷の転帰に関す る報告9)}

ビスコエラスティックデバイスによって得られる 情報が急性期対応を要する外傷診療において有益で あるか否かの指標として転帰との関連があげられ る. ビスコエラスティックデバイスの検査結果と外 傷症例の転帰との関連に関しては多くの報告が認め られる。主な報告内容としては, ROTEMの線溶元 進指標である confidence interval が $48 \%$ 以上の症例 の死亡率が $100 \%$ と報告されている。また，TEGに おける R と MA の 2 項目の異常は独立した予後因子 と報告されている. ROTEM の CFT 延長と血小板減 少が関与する MCF はいずれも予後不良と強い相関 が確認されており， Trauma and Injury Severity Score (TRISS) 式から予測される死亡率よりも不良な転帰 と強い相関を認めた。 ROTEMにおいて早期に把握 可能なフィブリノゲンの低下も不良な転帰と相関し ており，治療戦略においてもクリオ製剂やフィブリ ノゲン製剤の投与の基準になり得るとともに測定結 果をもとにした輸液・輸血量法による救命率改善も 報告されている.

TEG で測定可能な platelet mapping analysis の異常 所見は，血小板の機能低下を表すとともに頭部外傷 の死亡例においてより高頻度に認められたと報告さ れている。 また, TEGに招いて過凝固の症例は凝 固能が低下した症例より転機が良好との報告も認め られる。

\section{3. ビスコエラスティックデバイスを用いた外傷 治療アルゴリズム}

2015 年に Parkland Memorial Hospital から ROTEM ${ }^{\circledR}$ の検査結果に基づく外傷症例における輸血戦略のア ルゴリズムが具体的に報告されている。このことか らも現時点において米国におけるビスコエラス ティックデバイスの臨床現場での普及がなされてい ると考えられる ${ }^{10)}$ 。まずEXTEMにおいて ML が延 長していれば線溶立進と判断し抗線溶療法としてト
ラネキサム酸を投与し， CT が延長していれば凝固 能低下と判断し血漿を投与する。また，FIBTEMに おいて振幅が減少していればフィブリノゲン機能不 全と考えクリオ製剤やフィブリノゲン製郕の投与を 選択し，振幅が減少していなければ血小板機能不全 と判断し血小板投与を選択する.

一方, 中国の Nanjing Hospital からは2014 年に TEG を用いた腹部外傷に対する Goal-directed transfusion protocol が報告されている ${ }^{11)}$ ，まず初期血餅形成 までの時間を示す Rの延長を認めていればその程 度に応じた新鮮凍結血漿の投与量を決定する。次に 振幅が $20 \mathrm{~mm}$ に達するまでの角度であるフィブリン 網形成の速さを表す $\alpha$ angle が低下していればフィ ブリノゲン機能不全と考え新鮮凍結血漿投与後にク リオ製剤の追加投与を行う。 $\alpha$ angle が正常範囲で 血塊の強度を表す最大振幅である MA が減少して いれば血小板機能不全や凝固障害を考え新鮮凍結血 漿投与後の血小板輸血やリコンビナント第 VII 因子 製剂の投与を行う。諸外国においては，既にビスコ エラスティックデバイスを外傷性凝固障害の把握に 有効であり外傷診療に活用している報告が認められ る。今後，本邦においても外傷性診療の戦略におい て重要なデバイスとなりうると考えられる。

ただし，ビスコエラスティックデバイスの限界も 指摘されている. Cochrane Libraryでは以前よりビ スコエラスティックデバイスの限界は述べられてい たが12，2015 年の Reviewに拈いても前述したよう な外傷症例に関する論文にはバイアスが認められて おり，現時点ではエビデンスレベルが高い報告はな いのが現状である ${ }^{13)}$. 結論として現時点では外傷性 凝固障害において, PT や INR は完全ではないもの の現時点で臨床上最も信頼できるものであり $\mathrm{POC}$ 機器に関しては実験室の機器にとどめるべきとされ ている.この理由の一つに POC 機器で得られた解 釈が困難な結果に関する取り扱いが不十分である点 とされている. 現時点における心臓外科手術の術中 出血管理には有益であるが, 病態が異なる外傷症例 の輸血管理や転帰改善は有益であるとする明確な根 拠には至っていないのが現状である ${ }^{14)}$. 今後, 外傷 性凝固障害の治療戦略に役立てるためには, 複数の $\mathrm{POC}$ 機器の結果と臨床的に現時点で信頼性の高い PT や INRの結果を詳細に比較検討すべきである. 
また, POC 機器の測定上の問題点も検証し，臨床 応用する際の注意点を把握したうえで補助的な検査 項目としての有用性を検証する必要があると考えら れる。

著者の利益相反 $(\mathrm{COI})$ の開示 :

阪本雄一郎：講演料・原稿料など(旭化成ファーマ 株式会社)。

その他著者全員の利益相反 $(\mathrm{COI})$ の開示 :

本論文発表内容に関連して開示すべき企業との利益 相反なし

\section{文献}

1）外傷専門診療ガイドライン。外傷治療戦略 1 蘇生に必 要な治療戦略, 一般社団法人日本外傷学会監修, 日本 外傷学会外傷専門診療ガイドライン編集委員会編集, 東京, へるす出版, 2014, 19-31.

2）田中健一，小川覚：Viscoelastic Device-原理と使い方 · 注意点. Thrombosis Medicine 5: 158-164, 2015.

3) Hartert H: Blutgerinnungsstudien mit der Thrombelastographie, einem neuen Untersuchungsverfahren. Klin Wochenschr 26: 577-583, 1948.

4) Kang YG, Martin DJ, Marquez J, Lewis JH, Bontempo FA, Shaw BW, Starzl TE, Winter PM: Intraoperative changes in blood coagulation and thrombelastographic monitoring in liver transplantation. Anesth Analg 64: 888-896, 1985.

5) von Kaulla KN, Ostendorf P, von Kaulla E: The impedance machine: a new bedside coagulation recording device. J Med 6: 73-88, 1975.

6) Spahn DR, Cerny V, Coats TJ, Duranteau J, FernándezMondéjar E, Gordini G, Stahel PF, Hunt BJ, Komadina R, Neugebauer E, Ozier Y, Riddez L, Schultz A, Vincent JL, Rossaint R; Task Force for Advanced Bleeding Care in Trauma: Management of bleeding following major trauma: a Eu- ropean guideline. Crit Care 11: R17, 2007.

7) Spahn DR, Bouillon B, Cerny V, Coats TJ, Duranteau J, Fernández-Mondéjar E, Filipescu D, Hunt BJ, Komadina R, Nardi G, Neugebauer E, Ozier Y, Riddez L, Schultz A, Vincent JL, Rossaint R: Management of bleeding and coagulopathy following major trauma: an updated European guideline. Crit Care 17: R76, 2013.

8) Camazine MN, Hemmila MR, Leonard JC, Jacobs RA, Horst JA, Kozar RA, Bochicchio GV, Nathens AB, Cryer HM, Spinella PC: Massive transfusion policies at trauma centers participating in the American College of Surgeons Trauma Quality Improvement Program. J Trauma Acute Care Surg 78: S48-53, 2015.

9) Da Luz LT, Nascimento B, Shankarakutty AK, Rizoli S, Adhikari NK: Effect of thromboelastography $\left(\mathrm{TEG}^{\mathbb{B}}\right)$ and rotational thromboelastometry $\left(\right.$ ROTEM $\left.^{\circledR}\right)$ on diagnosis of coagulopathy, transfusion guidance and mortality in trauma: descriptive systematic review. Crit Care 18: 518, 2014.

10) Abdelfattah K, Cripps MW: Thromboelastography and rotational thromboelastometry use in trauma.Int J Surg 16: S17439191, 2015.

11) Yin J, Zhao Z, Li Y, Wang J, Yao D, Zhang S, Yu W, Li N, Li J: Goal-directed transfusion protocol via thrombelastography in patients with abdominal trauma: a retrospective study. World J Emerg Surg 9: 28, 2014.

12) Afshari A, Wikkelsø A, Brok J, Møller AM, Wetterslev J: Thrombelastography (TEG) or thromboelastometry (ROTEM) to monitor haemotherapy versus usual care in patients with massive transfusion. Cochrane Database Syst Rev CD007871, 2011.

13) Hunt H, Stanworth S, Curry N, Woolley T, Cooper C, Ukoumunne O, Zhelev Z, Hyde C: Thromboelastography (TEG) and rotational thromboelastometry (ROTEM) for trauma induced coagulopathy in adult trauma patients with bleeding. Cochrane Database Syst Rev 2: CD010438, 2015.

14) Levi M, Hunt BJ: A critical appraisal of point-of-care coagulation testing in critically ill patients. J Thromb Haemost 13: 1960-1967, 2015. 